\title{
Early internationalization patterns and export market persistence: A pseudo-panel data analysis
}

\author{
Yancy Vaillant \\ Department of Strategy and Entrepreneurship. Toulouse Business School (TBS) \\ 1 Place Alphonse Jourdain, 31068 TOULOUSE Cedex 7, France \\ Email: y.vaillant@tbs-education.org \\ Esteban Lafuente \\ Department of Management, Universitat Politècnica de Catalunya (Barcelona Tech) \\ EPSEB, Av. Gregorio Marañón, 44-50, 2da planta. 08028. Barcelona. Spain \\ Email: esteban.lafuente@upc.edu \\ Manoj Chandra Bayan \\ Departamento de Gestión de Organizaciones, Pontificia Universidad Javeriana de Cali \\ Calle 18 No 118-250 Cali, Colombia \\ Email: manoj.bayan@javerianacali.edu.co
}

\begin{abstract}
This study evaluates the international market persistence of early exporting businesses. The relationship between time in the market and export propensity/intensity levels was analyzed to identify the persistence of the internationalization patterns of entrepreneurial ventures. The empirical application employs a pseudo-panel approach at the business age- and industry-based cohort level drawn from a group of independent cross-sectional surveys that include information for 13961 independently and randomly-selected business owners for the period 2007-2012. The results show that the proportion of firms that export significantly diminishes following the initial post start-up years and that low export intensity levels at startup leads to greatest tenacity and persistence of the exporting efforts for new firms. The results contribute to the recent discussions on whether early internationalization is an effective strategy and should be encouraged.
\end{abstract}

Keywords: Market persistence, entrepreneurial internationalization, export propensity, export intensity, pseudo-panel data analysis.

JEL classification: L26, M13, M21

\section{CITE AS:}

Vaillant, Y, Lafuente, E., Bayon, M. (2018). Early internationalization patterns and export market persistence: A pseudo-panel data analysis. Small Business Economics, in press, doi: https://doi.org/10.1007/s11187-018-0071-z 


\section{Early internationalization patterns and export market persistence: A pseudo-panel data analysis}

\section{Introduction}

In an increasingly globalized world, the international competitiveness of firms has become important for overall economic prosperity (Chiao et al. 2006; OECD 2016; Puig et al. 2014). Moreover, a high proportion of international firms is beneficial to the economy as evidence shows that international firms tend to be more competitive and grow faster than noninternationalizing ones (Hollender et al. 2017; Pangarkar 2008; Zhou and Wu 2014). From the perspective of entrepreneurship policy making, the earlier SMEs start internationalizing and the more they internationalize, the sooner and greater would be their contribution to the economy. As such, promoting internationalization becomes an important policy concern.

However, new firms face several age-related constraints, such as shortage of qualified human capital, organizational resources, knowledge and experience related to production processes, technology as well as foreign market experience (Carr et al. 2010; Paul et al. 2017). Received wisdom from studies undertaken in entrepreneurship and international business argue that to overcome such constraints new firms need 'time in the market' before they can start consolidating their international market activities (Baptista et al. 2008; Fritsch and Noseleit 2013; Johanson and Vahlne 1977, 2009; Vernon 1971). Yet, an increasing number of new firms are becoming international soon after birth. In recent years, early internationalizing firms, known as 'born-global firms' or 'international new ventures', have received increased attention (Kalinic and Forza 2012; Knight and Cavusgil 2004; Knight and Liesch 2016; McDougall et al. 1994; Oviatt and McDougall 1994). Yet, considering the high exit rates of new firms, the consequences of over-estimating one's international market potential is possibly detrimental to new firms (Sapienza et al. 2006). Therefore, in light of existing theories of internationalization and the recent evidence of born global firms it is necessary to examine the persistence over time of export market entrepreneurial initiatives if early internationalization is to be encouraged.

Empirical studies of the choice of the internationalizing patterns of new firms and its consequences over their international market persistence remain unaddressed. For instance, most analyses on the performance implications of early internationalization are cross-sectional in nature (Ribau et al. 2016). Research has mostly focused on identifying the antecedents of early internationalization (Madsen and Servais 1997; Martineau and Pastoriza 2016), or in the case of born-global firms, has been limited by the use of small sample sizes and non-random case studies from high-tech industries (Rialp et al. 2005; Taylor and Jack, 2013; Westhead et al. 2001). Therefore, the main aim of our paper is to provide an insight into the internationalization process by carrying out a longitudinal analysis of international persistence in terms of export 
propensity and export intensity. More specifically, we examine how the early internationalization patterns of new businesses condition their export market persistence.

Instead of analyzing the determinants and/or the performance consequences of export propensity—i.e., the export decision—or export intensity—i.e., proportion of sales overseas(Calof, 1994; Salomon and Shaver, 2005), this study focuses on the export market persistence of businesses, defined in this study as the duration that export propensity and intensity levels are maintained (Eaton et al. 2007; Sapienza et al. 2006). Longitudinal data constitutes the ideal type of information to test export persistence. Nevertheless, in many countries, there is little longitudinal data on entrepreneurial behavior and the internationalization patterns of entrepreneurial businesses; while rich independent cross-sectional entrepreneurship surveys are available (e.g., adult population surveys generated by the Global Entrepreneurship Monitor, GEM). Samples of these surveys are drawn in different (and/or consecutive) periods so that the unit of analysis (e.g., individuals, entrepreneurial ventures) cannot be tracked down over time.

Therefore, building on a sample of 13961 business owners drawn from a series of independent randomly-selected cross-sectional annual surveys for the period 2007-2012, we model economic relationships that are linear in parameters, and not necessarily so in data, and that include individual unobserved heterogeneity. To do this we apply a pseudo-panel data model (Deaton 1985) in which the sampled business owners are grouped into cohorts delimited by fixed and observable characteristics (firm age and industry membership). The novelty of our analytical approach relies on the application of panel data techniques on independent crosssectional data with the objective to track down a series of random samples from the same cohort produced from the annual surveys (Browning et al. 1985).

The proposed pseudo-panel model is a response to the absence of longitudinal data, and prior studies in the fields of health and environmental sciences (Bernard et al. 2011; JiménezMartín et al. 1988; Verbeek and Nijman 1992) as well as economics (Kim and Kang 2014) indicate that results are equally consistent, in terms of estimation accuracy, primarily because sample representativeness is constantly maintained by drawing new samples each year. Additionally, Deaton (1985) proposes that grouping individual observations into cohorts homogenizes the individual effects grouped in the same cell, thus reducing measurement errors. The resulting pseudo-panel data model (Deaton 1985) permits the analysis of the internationalization patterns of businesses with different market experience and their export persistence. Results indicate that when it comes to export market persistence, early and intense internationalization patterns are not preferable.

The structure of the paper is as follows. The following section presents the theoretical framework and hypotheses. Section 3 addresses the data, variables and methodology of the analysis. The empirical results are presented in Section 4. The final discussion and conclusions are offered in Section 5. 


\section{Literature review and hypotheses}

In international business research, there is a great deal of work that has looked at the issue of early versus late internationalization of firms (Jones et al. 2011; Keupp and Gassman 2009; Ribau et al. 2016). Most studies focus on the question whether early internationalization by new firms would improve firm performance, or whether new firms should delay and gradually internationalize to be in a better competitive position (Andersen 1993; Autio et al. 2000; Forsgren 2002). Proponents of early internationalization emphasize the benefits for 'born global' firms by portraying it as an increasingly accessible exercise for new ventures (McDougall et al. 1994; Rialp et al. 2005). Many of the recent studies on the internationalization patterns of new entrepreneurial ventures focus on the capability development of born global firms (Glaister et al. 2014; Martin et al. 2017; Weerawardena et al. 2017). The development of foreign digital technologies and the growth in international distributors as well as web-based sales outlets and online shopping platforms have drastically decreased the barriers of internationalization and have spurred exports. For a young firm, it is easier to internationalize sales today than it has been in the past. Easy access to international markets has contributed to the important rise in the number of born-global firms (Cavusgil and Knight 2015).

However, international success is far from guaranteed (Crick 2003; Mora 2015). There are two dominant constraints to learning and capability development when firms adopt an early internationalization pattern. Born global firms tend to omit the necessary resource allocations to foreign market activities and lack valuable accumulated experience from foreign markets (Zahra et al. 2000). International firms have been found to require an adjustment in their resource configurations to support cross-border activity as they extend the scope of their activity beyond national borders (Hitt et al. 1997).

Even though exporting remains the most common entry mode into international markets (Lafuente et al. 2015; Morgan et al. 2012), export-failure is a likely outcome resulting from the many uncertainties, complexities and high investments related with international venturing (Manolova et al. 2010; Sapienza et al. 2006). A new firms' international failure not only translates in the loss of its international investments, it can often have negative repercussions on the firm's domestic activities (Amiti and Weinstein 2011). For instance, heavy external finance of international operations often means that unsuccessful exporters will consequently face financial constraints for domestic operations (Smolarski and Kut 2011). This is compounded by the fact that small and novice exporters tend to gain smaller export revenues (Rauch and Watson 2003), which rarely cover the costs of initiating international trade operations in the short-term (Das et al. 2007). Since the low export persistence of new firms and short international venture duration has been documented (Eaton et al. 2007; Sapienza et al. 2006), it is likely that internationalization results in losses for many exporters (Mora 2015). Thus, taking into account 
the uncertain outcome of early internationalization, we may argue that new firms would be better positioned if they take advantage of the learning effects to stabilize and improve organizational performance before entering international markets.

To this effect, extant theories on firm internationalization such as the process theory of internationalization (PTI), also known as the Uppsala model, argue that the internationalization process of the firm should proceed slowly and gradually (Autio and Sapienza 2000; Eriksson et al. 1997). Melitz (2003) highlight the connection between self-selection and the Uppsala model. Self-selection is a central economic theory arguing that only the most productive firms are able to compete in international markets. A gradual process of internationalization is said to improve performance because it allows firms to take advantage of organizational learning (Forsgren 2002). For instance, gradual internationalization gives firms the capacity to learn about their capabilities and needs for international expansion (Eriksson et al. 1997). Greater learning and capacity building allow firms to better adapt to the complexities of foreign markets and better respond to the specificities of foreign buyer needs. Learning and capability development is the result of the progressive speed, scope and consequent effectiveness of prior internationalization efforts (Chang 1995). Such accumulated foreign market experience provides firms with local market knowledge allowing them time to develop routines and processes for dealing with the foreign context (Barkema et al. 1997).

Indeed, most (traditional) models of internationalization argue that firms should internationalize gradually through a series of evolutionary stages (Bell and McNaughton 2000); where the first stage is based on gaining an adequate foothold over the domestic market prior to any international market expansion (Chang 1995). Therefore, the traditionalists that include the Uppsala school of thought suggest a later internationalization to improve export market persistence (Andersen 1993; Forsgren 2002). In other words, new firms should not rush into export operations at start-up or soon afterwards, but rather defer and adopt a later internationalization pattern. We therefore hypothesize that as compared to deferred internationalization at a later age:

H1: Early internationalization generates less persistent export-propensity levels.

However, the growing significance of born-global firms (Rialp et al. 2005) suggests that the debate should not focus exclusively on early or late internationalization, but also include the level of early export intensity (export to total sales ratio) that firms should pursue. For instance, should early internationalizing start-ups follow a high or a low intensity pattern? In the gradual internationalization approach, established capabilities are critical in explaining successful internationalization. Thus, experience-driven capability development is an important aspect of organizational learning that firms wishing to internationalize should possess. As a result, a low 
export intensity pattern for new firms allows for this type of experiential learning (Autio et al. 2000; Cope 2005).

A strategy based on low exports may be recommended for early international firms as internationalizing firms with substantial commitment to the domestic market may not have the necessary resources to successfully commit to international markets. In fact, rapid international growth may be destabilizing to new firms as their limited resources and capabilities may be overly stretched (Chetty and Campbell-Hunt 2003; Sapienza et al. 2006). As such, when firms 'over'-internationalize early they are even more likely to be handicapped by the lack of experience as well as capabilities that are critical for operating in international markets (Das et al. 2007). Because capabilities and the social capital to operate in an international market take time to develop, we suggest new firms that decide to follow an early internationalization pattern should do so with a low export intensity level. In other words, born global firms face resource and capability deficiencies to successfully adopt high export intensity patterns. Doing so is likely to negatively affect the ability of early international firms to maintain high levels of export intensity over time. We therefore hypothesize that as compared to early internationalization with lower export intensity levels:

H2: Early internationalization with a high export to sales ratio generates less persistent exportintensity levels.

\section{Sample and cohort definition, variables and method}

\subsection{Sample and cohort definition}

The data used in this study comes from the raw data collected as part of the adult population survey (APS) of the Global Entrepreneurship Monitor (GEM) in Spain for the period 2007-2012. The dataset is a very rich source of information containing consistent annual crosssectional data from a random sample of adult individuals on variables related to entrepreneurial activities, as well as individuals’ and businesses’ profiles (Lafuente et al. 2017; Reynolds et al. 2005). The final sample used in this study includes information for 13961 business owners (2007 $=2301$ observations, $2008=3011$ observations, $2009=2284$ observations, $2010=2334$ observations, 2011= 1887 observations, and 2012= 2144 observations). However, these surveys, as with many similar social science observatories, are cross-sectional in nature and do not follow individuals over time. Given the characteristics of such a dataset, accurate longitudinal analyses based on independent cross-sections require an efficient grouping of individuals.

To overcome the lack of longitudinal data, Deaton (1985) proposes an analysis based on a pseudo-panel composed of cohorts as units of analysis. A cohort is defined as a group with fixed membership, where observations belonging to each cohort $(C)$ share specific and observable characteristics (Deaton, 1985). In a pseudo-panel, observations are grouped into 
independent cohorts (from the different cross-section data) and cohort means are treated as observations in a synthetic panel that tracks down the series of random samples from the same cohort produced from the annual surveys (Browning et al. 1985). As the APS raw data provides consistent random samples drawn from the population, this guarantees variation in the observed cohort means over time. This random sampling procedure also eliminates potential attrition bias (Bernard et al. 2011; Browning et al. 1985).

Concerning the construction of the cohorts, note that more than one variable can be used to define cohorts. The chosen variables should be constant over time for each individual as they cannot move from one cohort to another, and they have to be observable for the whole sample. In this study, the unit of the analysis is the business owner, and individuals are grouped into cohorts according to two relevant characteristics: firm age and industry. In the case of the first criterion (firm age), the data includes detailed information on the exact start-up year for the sample business owners in each survey between 2007 and 2012. This way, the first criterion is firm age measured as the number of years of market experience. Under this condition 13 intervals were created, indicating whether the firm is in its first year of operations, second year in the market, third year in the market, fourth year in the market, fifth years in the market, sixth year in the market, seventh year in the market, eighth year in the market, ninth year in the market, tenth year in the market, from the 11th to the 15th year in the market, from the 16th to the 20th year in the market, and more than 20 years of operations.

The second criterion is the industry in which the businesses operate. Here observations were grouped into three different cohorts: manufacturing industry, business services sectors, and customer services sectors. Based on these two criteria we created a total number of $13 \times 3=39$ cohorts that are observed over a period of six years (2007-2012). Therefore, the final sample consists of 234 cohort-year observations.

At this point, it should be kept in mind that aggregation into cohorts implies a trade-off between cohort size and the number of cohorts. Smaller number of observations in each cohort indicates that cohort average values are inaccurate estimators of the true population means, while a small number of cohorts may lead to less precise model estimations (Deaton 1985; Verbeek and Nijman 1992). When the number of observations per cohort is large enough, the measurement error problem can be ignored (Browning et al. 1985; Blundell et al. 1989). Table 1 shows the distribution of cohorts by type of industry. In our sample, the average cohort size is 309.80 observations (ranging between 80 and 1513 observations). Consequently, cohorts are large enough to ignore measurement errors of population means, and this is evidence of an adequate balance between cohort size and number of cohorts (Deaton 1985). 


\subsection{Variables}

Dependent variable. Similar to other studies we use two variables to measure internationalization activity (e.g., Katsikeas et al. 2000; Majocchi et al. 2005). First, export market participation is measured through a dummy variable that takes the value of one if the business exports, and zero otherwise (export propensity). The second variable captures different levels of export intensity (proportion of export sales to total sales) and follows the widely accepted categorization proposed by the OECD (e.g., OECD: www.data.oecd.org): low intensity (ratio of international sales to total sales: less than 25\%), mid intensity (ratio of international sales to total sales: between $25 \%$ and $75 \%$ ), and high intensity (ratio of international sales to total sales: more than $75 \%)$. Note that only firms with international sales propensity are considered within these categories. Firms with no export sales do not form part of the low intensity category. This categorization proportionately divides the export intensity variable into quartiles in order to facilitate comparison across standardized categories and follow the usual export intensity categorization. Because of the skewness of the distribution in export intensity across international firms, this quartile-based categorization is considered more illustrative as compared to the alternative binomial 'foreign market focus'-'domestic foreign focus' categorization also found in the literature, which uses a simple 50\% cut-off (Vendrell-Herrero et al. 2017; Zhang et al. 2007). Following Deaton (1985), the OECD categorization is viewed as appropriate as it also allowed each category to surpass a minimum critical cohort size. Descriptive statistics at the individual level are presented in Table 2.

--- Insert Table 2 about here ---

Firm age. To identify the internationalization patterns adopted by new and established businesses, we introduced ten dummy variables linked to different levels of market experience (years in the market). These variables take the value of one for cohorts that include businesses with the corresponding number of years in the market: the cohort of businesses in the first two years of market operations (less than 2 years of market experience), the cohort of businesses in the third year of operations, the cohort of businesses in the fourth year of operations, the cohort of businesses in the fifth year of operations, the cohort of businesses in the sixth year of operations, the cohort of businesses in the seventh year of operations, the cohort of businesses in the eighth year of operations, the cohort of businesses in the ninth year of operations, the cohort of businesses in the tenth year of operations, and the cohort of businesses with more than ten years of market experience. For each cohort, these variables represent the average value (proportion of firm) for the observations within the focal cohort. In all models, the proportional value of new firms in their first two years of operations is the reference category. Note that the 
average age of firms within the cohort of new firms is of 1.04 years in the market (median of 1 ). Established firms have an average age of 14.53 years in the market (median of 12).

Control variables. We control for business size, business demography, the profile of the business owners (gender, age, and education), as well as industry, location, fluctuations in business demography and time in all model specifications. These mostly stem from existing empirical research (cited below) that may lead to suspicions of the presence of correlation between these control variables and the analyzed dependent variables. By adding these to our model we capture and isolate any hidden effects that may be influencing the relation between our dependent and hypothesized independent variables.

Following findings by Hutchinson et al. (2005) on the role of business size on international market expansion, business size is measured as the log of the number of employees. The sampled entrepreneurial ventures report, on average, 4.09 employees, and the new businesses in their first two years of operations show a significantly lower employment level (3.25 employees), compared to businesses with more years in the market (4.26 employees) (Table 2). A set of variables associated with the entrepreneur's profile was included: a dummy variable for gender (one for male, and zero otherwise) (Orser et al. 2010), age of the individual expressed in years (Lee et al. 2016) and a set of dummy variables accounting for the different levels of education attainment (primary studies, secondary studies, and post-secondary studies) (Suzuki et al. 2017). To account for the differences in the internationalization patterns of businesses across industries (Javalgi et al. 2000), we introduce three dummy variables that group businesses in three wide industry categories: manufacturing, business services and consumer services sectors. We created a series of dummy variables that identify the location of the sampled businesses across the 17 Spain's Autonomous Communities. For the variables business size, business demography, the business owners' profile, industry and location, the values represent, for each cohort, the average (proportion of businesses) reported for the observations within the focal cohort. Finally, changes in the economic conditions are captured via two variables. First, to capture fluctuations in business demography (Wagner 2015), we introduced a variable that measures the net business flow in the economy defined as the difference between business entries and exits relative to the stock of businesses in the previous period. The information to create this variable was obtained from the Spanish Statistical Institute (INE). Second, a set of time dummies are included to rule out the potential effect of trends and changes in the economic conditions during the analyzed period.

Concerning the econometric approach, panel-data analysis is the most efficient tool when the sample is a mixture of time series and cross-sectional data, since this structure allows taking into consideration the unobservable and constant heterogeneity, i.e., the specific characteristics of each observation. Panel data models have the following form: 
$y_{i t}=\beta_{j} X_{i t}+\eta_{i}+\varepsilon_{i t} \quad i=1,2, \ldots, N$ and $t=1, \ldots, T$

where $y_{i t}$ is the observed dependent variable for unit $i$ at period $t, X_{i t}$ is the vector of exogenous explanatory variables, $\beta$ is a vector of parameter estimates linked to the $j$-th independent variable, $\eta_{i}$ is an unobserved individual effect and $\varepsilon_{i t}$ is the normally distributed disturbance term estimated for each observation in the sample. The estimation of equation (1) requires information for the same observations $(N)$ at different time periods $(T)$ so that the analysis of the static and dynamic relations of interest is possible. Taking into account that our analysis is based on a pseudo-panel, once the cohorts are fully identified (see Section 3.1), the model to be estimated has the following form:

$\bar{y}_{c t}=\beta_{j} \bar{X}_{c t}+\bar{\eta}_{c}+\bar{\varepsilon}_{c t} c=1,2, \ldots, C$ and $t=1, \ldots, T$

where $\bar{y}_{c t}$ and $\bar{X}_{c t}$ are the average values of all observations in cohort $c$ at time $t ; \bar{\eta}_{c}$ is the average of the unobserved individual effect for observations in cohort $c$. The main shortcoming of the estimation of this model is that $\bar{\eta}_{c}$ depends on $t$ and is likely correlated with $\bar{X}_{c t}$ (Deaton 1985; Verbeek and Nijman 1992). Thus, treating $\bar{\eta}_{c}$ as fixed will result in an identification problem unless $\bar{\eta}_{c}$ stays constant over $t$. Nevertheless, $\bar{\eta}_{c}$ can be treated as a true cohort effect when the number of observations per cohort is sufficiently large so that the measurement error at the cohort level is minimized (Browning et al. 1985). Verbeek and Nijman (1992) confirmed that large cohorts overcome potential problems related to the intrinsic characteristics of cohorts (average values). These authors show that the variance of the measurement error decreases as the number of observations in the cohort grows.

Even though the pseudo panel approach used in this study is mainly adopted as a response to the absence of longitudinal data, this technique does not necessarily give inferior results (Bernard et al. 2011; Verbeek and Nijman 1992). The use of sample means from the different cross-sectional surveys will yield consistent estimators of the different variables from year to year. Nevertheless, it should be noted that the aggregation into cohorts implies that the mean value of the different variables used in the study are constant for each individual in the cohort from one year to the next. Therefore, the interpretation of results emerging from the use of cohort means in the analysis should be taken with some caution as the estimated parameters reflect homogenous average effects of the independent variables analyzed.

Based on the notation presented in equation (2), the full model used to test our hypotheses follows:

$$
\begin{aligned}
\overline{\text { Export activity }}_{c t} & =\beta_{0}+\beta_{1} \overline{\text { Firm age }}_{c t}+\beta_{2} \overline{\text { Control variables }}_{c t} \\
& +\beta_{3} \text { Time }_{t}+\bar{\eta}_{c}+\bar{\varepsilon}_{c t}
\end{aligned}
$$


In equation (3), $\beta_{0}$ is a constant term, $\beta_{j}$ is a vector of parameter estimates, $\bar{\eta}_{c}$ refers to the unobserved heterogeneity for observations in cohort $c$ and $\bar{\varepsilon}_{c t}$ is the error term. The dependent variable, export activity, represents export propensity—for each cohort, the proportion of exporters - and export intensity measured, for each cohort, as the proportion of observations falling within each of the analyzed export categories (low, medium and high). Control variables are the mean cohort values of business size, the business owners' profile (gender, age and education), industry and location. The variable 'net business flow' captures annual variations in the stock of businesses at national level, while 'time' is a set of dummy variables that identify each of the analyzed periods (2012 is the reference time category).

Although our dependent variable is a dummy variable, the fact that estimations are based on cohort means validates a linear analysis. This is so because the transformed dependent variables report for each cohort the proportion of observations with the desired property (export market participation). Also, it is worth noting that the number of observations varies by cohort and that observations are heterogeneous. This implies that the model presented in equation (3) is likely to be subject to heteroskedasticity. In order to control for heteroskedasticity in the error terms, we adopt the approach by Deaton (1985, p. 117) so that in the estimation of the different model specifications cohorts are weighted by the square root of their size.

Equation (3) is estimated by random-effects panel data generalized least squares (GLS) models with robust standard errors to correct for autocorrelation of disturbances due to constant cohort-specific effects (Greene 2003). This approach is especially suitable for our analysis because the key variables measuring the effect of market experience on the internationalization persistence of businesses is fixed over time.

We estimated the Hausman (1978) specification test to further validate the appropriateness of the proposed regression models. Results for the export propensity model (Hausman test: 19.06 and $p$-value $=0.3880$ ) and for the export intensity models (Hausman test (low export intensity): 18.02 and $p$-value $=0.4542$; Hausman test (mid-export intensity): 19.61 and $p$-value $=0.3550$; and Hausman test (high export intensity): 6.89 and $p$-value $=0.9910$ ) indicate that random effects estimations are independent of cohort-specific effects-i.e., regressors are consistent- thus confirming that random-effects coefficients are consistent and efficient (Wooldridge 2002).

\section{Results}

This section presents the results of the pseudo-panel data model. Table 3 shows both the results of export propensity and export intensity for the different cohorts of firms based on their time since start-up. In the first column of Table 3 we find the results of the full model based of the export propensity of firms. These results show if there is a significant difference between the 
proportion of firms that export (within the observed cohorts) in comparison with the reference cohort comprising newly created firms (firms within their first two years of business).

--- Insert Table 3 here ---

The results of the control variables indicate that the business flow rate positively influences the export propensity and low export intensity of the analyzed cohorts. This is in line with prior work suggesting that export activity increases in years of economic prosperity (Awokuse 2005; Balassa 1985; Harrison 1996). Another control variable found to influence export intensity is the level of maximum educational attainment on the part of the business owner. Lower educational levels are associated with lower levels of export intensity, while secondary studies are linked to mid-level export intensity at start-up, and high export intensive businesses are led significantly more by entrepreneurs with post-secondary level education (University) than those with only basic educational attainments.

In the case of the study's first dependent variable, export propensity, the results show how the proportion of exporting firms significantly reduced up to the fourth year in the market as compared to the proportion of exporters in the cohort of newly created firms. For illustrative purposes, Figure 1 presents the empirically constructed internationalization trajectory based on estimates from Table 3 (full model). In the figure, control variables are set at their sample means. In line with the tenor of the results in Table 3, Figure 1 shows the fall in the predicted proportion of exporting businesses at the cohort level after the first two years of operations.

This is an indication that newly created firms would tend to overestimate their export market potential at start-up. There are two interpretations to this result. Either, a greater proportion of exporting firms, as compared to non-exporting ones, fail to survive past their first two years of business and therefore are proportionally less numerous in subsequent cohorts of firms in their third and fourth year in the market. Or, a second interpretation would be that many of the surviving exporters from the cohort of newly created firms choose to abandon their international operations in their third and fourth year in the market. Whichever way, what is found is a significantly lower proportion of exporters among cohorts of firms in their third and fourth year in business, compared to that reported for newly created businesses.

--- Insert Figure 1 here ---

This result shows that firms adopting an early export pattern (born-global) are often unsuccessful in these international ventures and tend to retract out of export markets or exit the market. This confirms the first hypothesis (H1) that proposes that early, as compared to later, internationalization generates less persistent export-propensity levels. Additional checks to 
better detail this result (see Table A1 in the Appendix) appear to indicate that, for our sample, the loss in export propensity with the increase in the number of years in the market is especially relevant for cohorts of firms operating in the manufacturing sector.

The second, third and fourth columns of Table 3 show the results of the pseudo-panel estimations for the different levels of export intensity: low export intensity firms with exports representing less than $25 \%$ of their total sales (column two); mid-intensity firms with between $25 \%$ and $75 \%$ of their total sales being international (column three); and firms with high export intensity that export over $75 \%$ of their total sales (column four).

Again, the reference category of the 'firm age' variable against which cohorts are being compared is the one encompassing the newly created firms in their first two years of business. If we begin with the results for the low export intensity firms, it can be seen how as compared to newly created firms, the proportion of firms that export but do so in a proportion that is less than $25 \%$ of their total sales increases after the second year in the market. The results show how the cohorts of firms that have been operating in the market for three and up to six years have significantly greater proportions of low intensity exporters as compared to the cohort of newly created businesses.

This increase in the proportion of low-intensity export firms can come from two sources. First, there are those cohorts of firms that have adopted a deferred internationalization pattern by starting their operations without any export activity. These firms have then decided to engage in international activities as low-intensity exporters only once their initial years as a newly created firm in the market had past. The second argument to explain the significant increase in the proportion of low-intensity export firms in cohorts past the first two years of business relates to the mid to high intensity exporters at start up that have subsequently either diminished their level of international sales or have seen their domestic sales increase at a relatively higher rate. By lowering their export intensity to levels below $25 \%$ of total sales, these firms have come to form part of the low-intensity export category following their initial years in business. They have therefore contributed in increasing the proportion of low-intensity exporters of cohorts of firms in their third and up to sixth year in the market to levels that are significantly greater than those demonstrated within the base cohort of newly created firms.

This second source of low-intensity post start-up exporters (after the initial two years of operations) is further supported by the results found in the mid-level and high-intensity exporters (columns 3 and 4 in Table 3). Cohorts including firms beyond their initial years in the market in both these categories significantly diminish the proportions of exporters as compared to levels found in the base cohort of newly created firms. This is especially evident in the case of high-intensity exporters that when compared to newly-created firms have significantly lower proportions of businesses exporting over $75 \%$ of their sales, and this is so year after year for an entire decade following start-up. The same happens in the case of mid-level international firms 
with proportions of medium intensity exporters being significantly inferior to those found in the cohort of newly created firms for all cohorts of businesses up to five years in the market. This may mean that a significant number of newly created firms overshoot their optimal export levels at start-up and adjust down their export intensity or increase the proportion of their domestic sales during their subsequent years in business. The export sales of these firms come to occupy a lower proportion of total sales. This is the interpretation for surviving businesses; but the obtained results can also be a sign that those firms with highest export intensity are those that most tend to fail in their early years in the market (Sapienza et al. 2006).

To better understand the rise in the proportion of firms with low-intensity internationalization as time in the market increases, the results of further analysis are shown in Table 4. These findings indicate that the increasing proportions of low-intensity exporters appear to come mostly from the shift down of firms previously having medium or high export intensity levels. This would seem to represent an adjustment by firms that may have overextended their early international market operations. Likewise, the commented rise in the rate of low-intensity exporters can also be the result of firms that have deferred their international market activities as low-intensity exporters in their third or more years of operations.

To aid in the interpretation of the results, Figures 2 and 3 display the empirically constructed trajectory of internationalization based on estimates from Table 4. In the figures, the vertical axis indicates the predicted level of export intensity at the cohort level (Figure 2: export intensity $<25 \%$, Figure 3: export intensity $>25 \%$ ), while the horizontal axis indicates firm age. Control variables are set at their sample means. Figure 2 graphically illustrates that the relationship between low export intensity (export to sales ratio $<25 \%$ ) and market experience is positive for cohorts formed by businesses with up to five years of operations. In subsequent periods, the proportion of businesses exporting less than $25 \%$ of their sales shows a slightly decreasing (and not significant) trend that stabilizes for cohorts including businesses with more than ten years of experience. This result is consistent with the argument that businesses with low export intensity levels in their first years of operations show higher export persistence patterns over time. On contrary, Figure 3 shows that the predicted trajectory for the proportion of businesses exporting more than $25 \%$ of their sales drastically falls after the start-up period. After the severe adjustment in their exports, the temporal persistence of mid- and high-exports (exports to sales ratio $>25 \%$ ) turns stable after the fifth year of operations. These results support the second hypothesis formulated within this study (H2). Early internationalization with high export to total sales ratio generates less persistent export-intensity levels, as it is found that those initiating their market activities with mid-to-high export intensity from start-up tend to either be forced to adjust down their international operations or exit the market. 


\section{Discussion and concluding remarks}

The study presented in this paper contributes to the recent discussion and policy concerns surrounding the support to businesses' early internationalization process. The main objective was to provide better longitudinal insights into the internationalization of early exporting businesses. More specifically, by creating a pseudo-panel that includes information for 13961 business owners between 2007 and 2012, we examine how the early internationalization patterns of new businesses condition their international persistence in terms of export propensity and export intensity.

Founded on the dominant theoretical perspectives within the academic literature we proposed two hypotheses linking early internationalization patterns and international persistence; one that favors deferred international market entry, and another that favors lower export intensity levels for early international firms if international market persistence is the aim. The findings of our study show that, first, newly created firms tend to overestimate their export market potential. Consequently, these new businesses that adopt an early export pattern often tend to retract out of export markets or exit the market all-together. Those firms that deferred their international market entry past start-up tended to demonstrate a more assiduous export propensity. This is similar to what was proposed by Andersen (1993) and later found by Forsgren (2002). Second, a significant number of new international firms overshoot their optimal export levels at start-up and consequently are forced to abandon or significantly reduce their export intensity during their subsequent years in business. Overall, an internationalization pattern that involved a more gradual export intensity trajectory is found to result in greater tenacity and persistence of the exporting efforts for new firms. This is consistent with what was found by Chang (1995) who proposed that early internationalization did not allow for an appropriate accumulation of key capabilities required for international success. Newly created firms initiating their operations with highest export intensity levels were also those whose international operations least persevered in the subsequent years following their start-up.

\subsection{Implications}

From a policy perspective, these findings would tend to indicate that more persistent export propensity and intensity is much more likely to be reached through the promotion of a deferred and less intensive international expansion platform for newly created firms. An excessive emphasis on the part of entrepreneurship policy on rapid and intense internationalization of newly created firms may actually be counter-productive from an economic and entrepreneurial point of view (Das et al. 2007). For entrepreneurs, being international from birth, especially at high intensity levels, may take them past their capability frontier and over-stretch the newly created firms' organizational capacity. These young firms 
may inadequately respond to international opportunities and fail to meet expectations leading to disappointed foreign buyers and losses in their share of foreign market.

Policy should be especially careful when promoting the aggressive and rapid internationalization of newly created firms as the consequences to entrepreneurs and their firms of over-estimating their international market potential are possibly more detrimental than underutilizing such potential (Sapienza et al. 2006).

From a theoretical perspective, the results from our study bring balance back to a discussion between whether a gradual or an early internationalization pattern is best for newly created firms. By giving longitudinal evidence that potentially gives preference to a gradual internationalization trajectory when the goal is the greater tenacity and persistence of the export market operations of new entrepreneurial ventures, the results from this study diverges from the trend of publications over the last decades that have mostly advanced the merits of the born global approach (Cavusgil and Knight 2015; Knight and Liesch 2016; McDougall et al. 1994). Our research does not refute the findings from these many studies, mainly because the focus and analyzed dependent variables are different. Recent studies on the internationalization patterns of new entrepreneurial ventures focus mostly on the existence, antecedents, determinants and capability development of born global firms (Glaister et al. 2014; Martin et al. 2017; Weerawardena et al. 2017). The study presented in this paper pushes the analysis further towards a longitudinal perspective so as to appreciate the post start-up strength and international market persistence of new firms adopting these different internationalization patterns.

\subsection{Limitations and avenues for future research}

As in all social science research, no generalization can be drawn here and the deferred or gradual internationalization trajectory may not be suitable for all new ventures where certain firms promoted by experienced serial entrepreneurs or start-ups from specific industries and adopting specialized innovation strategies are concerned (Acs and Audretsch 1990). But for the average business captured by the study's sample of 13961 business owners surveyed between 2007 and 2012, the evidence produced by our longitudinal analysis does show that an early and intense internationalization pattern from start-up may not be the best export pattern to promote if a durable internationalization is sought after.

Limitations of this study and further specifications to it can be made in future research. One such limitation that can be surmounted through further research comes from the inability of the current study to deterministically distinguish whether the lack of export market persistence is due to the retrenchment of international activities, firm failure, or (in the case of export intensity) the relative superior growth of domestic sales. Although tests were performed that show the unlikeliness of this, our results indicating a negative correlation between the export intensity of early international firms and the persistence of this intensity, may be interpreted as a 
sign that highly intensive early internationalization disproportionately stimulates domestic sales performance. Only new research specifically targeted to address this issue could give a definite answer. Other obvious specifications for future research are related to aspects already mentioned above. The prior international and entrepreneurial experience of the entrepreneurial team launching a new venture may greatly accelerate learning processes and reduce the need for a gradual internationalization process (Rialp et al. 2005; Vaillant et al. 2006). Greater emphasis on productivity measure to better capture the self-selection influence over decisions of exporting contingent to productivity levels also constitute an avenue for further research. A break-down of the sample into specific competitive strategies adopted by new international ventures may allow us to find variations in their post start-up international market persistence.

\section{References}

Acs, Z.J., \& Audretsch, D.B. (1990). Innovation and Small Firms. Cambridge: MIT Press.

Amiti M., \& Weinstein D.E. (2011). Exports and financial shocks. Quarterly Journal of Economics, 126(4), 1841-1877. https://doi.org/10.1093/qje/qjr033

Andersen, O. (1993). On the internationalization process of firms: A critical analysis. Journal of International Business Studies, 24(2), 209-231. https://doi.org/10.1057/palgrave.jibs.8490230

Autio, E., \& Sapienza, H.J. (2000). Comparing process and born global perspectives in the international growth of technology-based new firms, Frontiers of Entrepreneurship Research (Center for Entrepreneurial Studies, Babson College), pp. 413-424.

Autio, E., Sapienza, H.J., \& Almeida, J.G. (2000). Effects of age at entry, knowledge intensity, and imitability on international growth. Academy of Management Journal, 43(5), 909-924. https://doi.org/10.2307/1556419

Awokuse, T.O. (2005). Exports, economic growth and causality in Korea. Applied Economics Letters, 12 (11), 693-696. https://doi.org/10.1080/13504850500188265

Balassa, B. (1985). Exports, policy choices, and economic growth in developing countries after the 1973 oil shock. Journal of Development Economics, 18(1), 23-35. https://doi.org/10.1016/0304-3878(85)90004-5

Baptista, R., Escária, V., \& Madruga, P. (2008). Entrepreneurship, regional development and job creation: the case of Portugal. Small Business Economics, 30(1), 49-58. https://doi.org/10.1007/s11187-007-9055-0

Barkema, H.G., Shenkar, O., Vermeulen, F., \& Bell, J.H J. (1997). Working abroad, working with others: How firms learn to operate international joint ventures. Academy of Management Journal, 40, 426-442. https://doi.org/10.2307/256889 
Bell, J., \& McNaughton, R. (2000). Born global firms: A challenge to public policy in support of Internationalization, in J. Pels and D.W. Stewart (Ed.), Marketing in a global economy (pp. 176-185). Buenos Aires, Argentina: American Marketing Association.

Bernard, J.T., Bolduc, D., \& Yameogo, N.D. (2011). A pseudo-panel data model of household electricity demand, Resource and Energy Economics, 33, 315-325. https://doi.org/10.1016/j.reseneeco.2010.07.002

Blundell, R.W., Browning, O.M., \& Meghir, C. (1989). A Microeconometric Model of Intertemporal Substitution and Consumer Demand. The Warwick Economics Research Paper Series (TWERPS) 324, University of Warwick, Department of Economics.

Browning, M., Deaton, A., \& Irish, M. (1985). A profitable approach to labor supply and commodity demands over the life-cycle. Econometrica, 53, 503-544. https://doi.org/10.2307/1911653

Calof, J. (1994). The relationship between firm size and export behavior revisited. Journal of International Business Studies, 25(2), 367-387. https://doi.org/10.1057/palgrave.jibs.8490205

Carr, J.C., Haggard, K.S., Hmieleski, K.M., \& Zahra, S.A. (2010). A study of the moderating effects of firm age at internationalization on firm survival and short-term growth, Strategic Entrepreneurship Journal, 4, 183-192. https://doi.org/10.1002/sej.90

Cavusgil, S.T., \& Knight, G. (2015). The born global firm: An entrepreneurial and capabilities perspective on early and rapid internationalization. Journal of International Business Studies, 46(1), 3-16. https://doi.org/10.1057/jibs.2014.62

Chang, S-J. (1995). International expansion strategy of Japanese firms: Capability building through sequential entry. Academy of Management Journal, 38, 383-407. https://doi.org/10.2307/256685

Chetty, S., \& Campbell-Hunt, C. (2003). Explosive international growth and problems of success amongst small to medium-sized firms. International Small Business Journal, 21(1), 5-27. https://doi.org/10.1177/0266242603021001719

Chiao, Y.C., Yang, K.P., \& Yu, C.M.J. (2006). Performance, internationalization, and firmspecific advantages of SMEs in a newly-industrialized economy. Small Business Economics, 26(5), 475-492. https://doi.org/10.1007/s11187-005-5604-6

Cope, J. (2005). Toward a dynamic learning perspective of entrepreneurship. Entrepreneurship Theory and Practice, 29(4), 373-397. https://doi.org/10.1111/j.1540-6520.2005.00090.x

Crick D. (2003). The international entrepreneurial decision of UK SMEs to discontinue overseas activities: A research note reporting practices within the clothing industry eighteen months on. Journal of International Entrepreneurship, 1(4), 405-413.

https://doi.org/10.1023/A:1025685509020 
Das S., Roberts., M. J., \& Tybout J. R. (2007). Market entry costs, producer heterogeneity, and export dynamics. Econometrica 75, 837-873. https://doi.org/ 10.1111/j.14680262.2007.00769.x

Deaton, A. (1985). Panel data from time series of cross-sections, Journal of Econometrics, 30, 109-126. https://doi.org/10.1016/0304-4076(85)90134-4

Eaton J., Eslava M., Kugler M., \& Tybout J. (2007). Export dynamics in Colombia: Firm-level evidence. Technical report, National Bureau of Economic Research.

Eriksson, K., Johanson, J., Majkgård, A., \& Sharma, D. (1997). Experiential knowledge and cost in internationalization process. Journal of International Business Studies, 28, 337-360. https://doi.org/10.1057/palgrave.jibs.8490104

Forsgren, M. (2002). The concept of learning in the Uppsala internationalization process model: a critical review. International Business Review, 11(3), 257-277. https://doi.org/10.1016/S0969-5931(01)00060-9

Fritsch, M., \& Noseleit, F. (2013). Investigating the anatomy of the employment effect of new business formation. Cambridge Journal of Economics, 37(2), 349-377. https://doi.org/10.1093/cje/bes030

Glaister, A., Yipeng, L., Sahadev, S., \& Gomes, E., (2014). Externalising, Internalising and Fostering Commitment - The Case of Born-global Firms In Emerging Economies. Management International Review, 54(4), 473-496. https://doi.org/10.1007/s11575-0140215-6

Greene, W. (2003). Econometric Analysis. Upper Saddle River, NJ: Prentice Hall.

Harrison, A. (1996). Openness and growth: A time-series, cross-country analysis for developing countries. Journal of Development Economics, 48(2), 419-447. https://doi.org/10.1016/0304-3878(95)00042-9

Hausman, J. (1978). Specification Tests in Econometrics. Econometrica, 46, 1251-1271. https://doi.org/10.2307/1913827

Hitt, M.A., Hoskisson, R.E., \& Kim, H. (1997). International diversification: effects on innovation and firm performance in product-diversified firms. Academy of Management Journal, 40, 787-798. https://doi.org/10.2307/256948

Hollender, L., Zapkau, F. B., \& Schwens, C. (2017). SME foreign market entry mode choice and foreign venture performance: The moderating effect of international experience and product adaptation. International Business Review, 26(2), 250-263. https://doi.org/10.1016/j.ibusrev.2016.07.003

Hutchinson, K., Quinn, B., \& Alexander, N. (2005). The Internationalisation of Small to Medium-Sized Retail Companies: Towards A Conceptual Framework. Journal of Marketing Management, 21(1-2), 149-179. https://doi.org/10.1362/0267257053166857 
Javalgi, R., White, S., \& Lee, O. (2000). Firm Characteristics Influencing Export Propensity: An Empirical Investigation by Industry Type. Journal of Business Research, 47, 217-228. https://doi.org/10.1016/S0148-2963(98)00065-4

Jiménez-Martín, S. Labeaga, J.M., \& Pérez, A. (1998). Participation, heterogeneity and dynamics in tobacco consumption: evidence from cohort data. Health Economics, 7, 401414. https://doi.org/10.1002/(SICI)1099-1050(199808)7:5<401::AID-HEC361>3.0.CO;2-2

Johanson, J., \& Vahlne, J.E. (1977). The internationalization process of the firm-a model of knowledge development and increasing foreign market commitments. Journal of International Business Studies, 8(1), 23-32. https://doi.org/10.1057/palgrave.jibs.8490676

Johanson, J., \& Vahlne, J.E. (2009). The Uppsala internationalization process model revisited: From liability of foreignness to liability of outsidership. Journal of International Business Studies, 40(9), 1411-1431. https://doi.org/10.1057/jibs.2009.24

Jones, M., Coviello, N., \& Tang, Y.K. (2011). International Entrepreneurship research (19892009): A domain ontology and thematic analysis. Journal of Business Venturing, 26(6), 632-659. https://doi.org/10.1016/j.jbusvent.2011.04.001

Kalinic, I., \& Forza, C. (2012). Rapid internationalization of traditional SMEs: Between gradualist models and born globals. International Business Review, 21(4), 694-707. https://doi.org/10.1016/j.ibusrev.2011.08.002

Katsikeas, C.S., Leonidou, L.C., \& Morgan N.A. (2000). Firm-level Export Performance Assessment: Review, Evaluation, and Development. Journal of the Academy of Marketing Science, 28, 493-511. https://doi.org/10.1177/0092070300284003

Kim, B.Y., \& Kang, Y. (2014). Social capital and entrepreneurial activity: A pseudo-panel approach. Journal of Economic Behavior \& Organization, 97, 47-60. https://doi.org/10.1016/j.jebo.2013.10.003

Knight, G.A., \& Cavusgil, S.T. (2004). Innovation, organizational capabilities, and the bornglobal firm. Journal of International Business Studies, 35(2), 124-141. https://doi.org/10.1057/palgrave.jibs.8400071

Knight, G.A., \& Liesch, P.W. (2016). Internationalization: From incremental to born global. Journal of World Business, 51(1), 93-102. https://doi.org/10.1016/j.jwb.2015.08.011

Keupp, M.M., \& Gassmann, O. (2009). The past and the future of international entrepreneurship: a review and suggestions for developing the field. Journal of Management, 35(3), 600-633. https://doi.org/10.1177/0149206308330558

Lafuente, E., Stoian, C., \& Rialp, J. (2015). From Export Entry to De-internationalisation through Entrepreneurial Attributes. Journal of Small Business and Enterprise Development, 22 (1), 21-37. https://doi.org/10.1108/JSBED-09-2012-0101

Lafuente, E., Vaillant, Y., \& Vendrell-Herrero, F. (2017). Territorial servitization: Exploring the virtuous circle connecting knowledge-intensive services and new manufacturing 
businesses. International Journal of Production Economics, 192, 19-28.

https://doi.org/10.1016/j.ijpe.2016.12.006

Lee, I. H., Paik, Y., \& Uygur, U. (2016). Does Gender Matter in the Export Performance of International New Ventures? Mediation Effects of Firm-specific and Country-specific Advantages. Journal of International Management, 22(4), 365-379. https://doi.org/10.1016/j.intman.2016.05.004.

Madsen, T.K., \& Servais, P. (1997). The internationalization of born globals: an evolutionary process? International Business Review, 6(6), 561-583. https://doi.org/10.1016/S09695931(97)00032-2

Majocchi, A., Bacchiocchi, E., \& Mayrhofer, U. (2005). Firm Size, Business Experience and Export Intensity in SMEs: a Longitudinal Approach to Complex Relationships. International Business Review, 14, 719-738. https://doi.org/10.1016/j.ibusrev.2005.07.004

Manolova T.S., Manev I.M., \& Gyoshev B.S. (2010). In good company: The role of personal and inter-firm networks for new-venture internationalization in a transition economy. Journal of World Business, 45(3), 257-265. https://doi.org/10.1016/j.jwb.2009.09.004

Martin, S. L., Javalgi, R. G., \& Cavusgil, E. (2017). Marketing capabilities, positional advantage, and performance of born global firms: Contingent effect of ambidextrous innovation. International Business Review, 26(3), 527-543. https://doi.org/10.1016/j.ibusrev.2016.11.006

Martineau, C., \& Pastoriza, D. (2016). International involvement of established SMEs: A systematic review of antecedents, outcomes and moderators. International Business Review, 25(2), 458-470. https://doi.org/10.1016/j.ibusrev.2015.07.005

McDougall, P., Shane, S., \& Oviatt, B. (1994). Explaining the formation of international new ventures: the limits of theories from international business research, Journal of Business Venturing, 9, 469-487. https://doi.org/10.1016/0883-9026(94)90017-5

Melitz, M.J. (2003). The impact of trade on intra-industry reallocations and aggregate industry productivity. Econometrica, 71(6), 1695-1725. https://doi.org/10.1111/1468-0262.00467

Mora J. (2015). Export Failure and Its Consequences: Evidence from Colombian Exporters. Working paper series, Department of Economics, Occidental College (California, USA). Morgan N.A., Katskieas C.S., \& Vrohies D.W. (2012). Export marketing strategy implementation, export marketing capabilities, and export venture performance. Journal of the Academy of Marketing Science, 40(2), 271-289. https://doi.org/10.1007/s11747-0110275-0

OECD (2016). Entrepreneurship at a Glance 2016, OECD Publishing, Paris. Available at http://dx.doi.org/10.1787/entrepreneur_aag-2016-en 
Orser, B., Spence, M., Riding, A., \& Carrington, C. (2010). Gender and Export Propensity. Entrepreneurship: Theory and Practice, 34(5), 933-957. https://doi.org/10.1111/j.15406520.2009.00347.x

Oviatt, B., \& McDougall, P. (1994). Toward a theory of international new ventures. Journal of International Business Studies, 25, 45-64. https://doi.org/10.1057/palgrave.jibs.8490193

Pangarkar, N. (2008). Internationalization and performance of small-and medium-sized enterprises. Journal of World Business, 43(4), 475-485. https://doi.org/10.1016/j.jwb.2007.11.009

Paul, J., Parthasarathy, S., \& Gupta, P. (2017). Exporting challenges of SMEs: A review and future research agenda. Journal of World Business, 52(3), 327-342. https://doi.org/10.1016/j.jwb.2017.01.003

Puig, F., González-Loureiro, M., \& Ghauri, P.N. (2014). Internationalisation for survival: The case of new ventures. Management International Review, 54(5), 653-673. https://doi.org/10.1007/s11575-014-0209-4

Rauch J.E., \& Watson J. (2003). Starting small in an unfamiliar environment. International Journal of Industrial Organization, 21, 1021-1042. https://doi.org/10.1016/S01677187(03)00018-3

Reynolds, P., Bosma, N., Autio, E., Hunt, S., De Bono, N., Servais, I., Lopez, P., \& Chin, N. (2005). Global Entrepreneurship Monitor: Data Collection Design and Implementation 1998-2003. Small Business Economics, 24, 205-231. https://doi.org/10.1007/s11187-0051980-1

Rialp, A., Rialp, J., \& Knight, G.A. (2005). The phenomenon of early internationalizing firms: what do we know after a decade (1993-2003) of scientific inquiry? International Business Review, 14(2), 147-166. https://doi.org/10.1016/j.ibusrev.2004.04.006

Rialp, A., Rialp, J., Urbano, D., Vaillant Y. (2005). The born-global phenomenon: A comparative case study research. Journal of International Entrepreneurship, 3 (2), 133-171. https://doi.org/10.1007/s10843-005-4202-7

Ribau, C.P., Moreira, A.C., \& Raposo, M. (2016). SME internationalization research: Mapping the state of the art. Canadian Journal of Administrative Sciences/Revue Canadienne des Sciences de l'Administration, in press. https://doi.org/10.1002/cjas.1419

Salomon, R., \& Shaver, J.M. (2005). Export and domestic sales: their interrelationship and determinants. Strategic Management Journal, 26(9), 855-871. https://doi.org/10.1002/smj.481

Sapienza, H., Autio, E., George, G., \& Zahra, S. (2006). A Capabilities Perspective on the Effects of Early Internationalization on Firm Survival and Growth. Academy of Management Review, 31(4), 914-933. https://doi.org/10.5465/AMR.2006.22527465 
Smolarski J., \& Kut C. (2011). The impact of venture capital financing method on SME performance and internationalization. International Entrepreneurship and Management Journal, 7(1), 39-55. https://doi.org/10.1007/s11365-009-0128-1

Suzuki, J., \& Okamuro, H. (2017). Determinants of Academic Startups' Orientation toward International Business Expansion. Administrative Sciences, 7(1), 1-20. https://doi.org/10.3390/admsci7010001.

Taylor, M., \& Jack, R. (2013). Understanding the pace, scale and pattern of firm internationalization: An extension of the 'born global' concept. International Small Business Journal, 31(6), 701-721. https://doi.org/10.1177/0266242611431992

Vaillant Y., Rialp, A., Rialp, J., Urbano, D. (2006). Un estudio cualitativo y exploratorio de cuatro nuevas empresas exportadoras. Cuadernos de Economía y Dirección de la Empresa, 29, 107-132. ISSN:1138-5758

Vendrell-Herrero, F., Gomes, E., Mellahi, K, \& Child, J. (2017) Building international business bridges in geographically isolated areas: The role of Foreign Market Focus and Outward Looking Competences in Latin American SMEs. Journal of World Business, 52(4), 489502. https://doi.org/10.1016/j.jwb.2016.08.007

Verbeek, M., \& Nijman, T. (1992). Can cohort data be treated as genuine panel data? Empirical Economics, 17, 9-23. https://doi.org/10.1007/BF01192471

Vernon, R. (1971). Sovereignty at bay: the multinational spread of US enterprises. New York: Basic Books.

Wagner, J. (2015). A Note on Firm Age and the Margins of Exports: First Evidence from Germany. International Trade Journal, 29(2), 93-102. https://doi.org/10.1080/08853908.2014.984796

Weerawardena, J., Mort, G.S., \& Liesch, P.W. (2017). Capabilities development and deployment activities in born global B-to-B firms for early entry into international markets. Industrial Marketing Management, in press. https://doi.org/10.1016/j.indmarman.2017.06.004

Westhead, P., Wright, M., \& Ucbasaran, D. (2001). The internationalization of new and small firms: A resource-based view. Journal of Business Venturing, 16(4), 333-358. https://doi.org/10.1016/S0883-9026(99)00063-4

Wooldridge, J.M. (2002). Econometric Analysis of Cross Section and Panel Data. Cambridge, MA: MIT Press.

Zahra, S., Ireland, R., \& Hitt, M.A. (2000). International expansion by new venture firms: International diversity, mode of market entry, technological learning, and performance. Academy of Management Journal, 43(5), 925-950. https://doi.org/10.2307/1556420

Zhang, Y., Li, H., Hitt, M.A., \& Cui, G. (2007). R\&D intensity and international joint venture performance in an emerging market: moderating effects of market focus and ownership 
structure. Journal of International Business Studies, 38(6), 944-960.

https://doi.org/10.1057/palgrave.jibs.8400301

Zhou, L., \& Wu, A. (2014). Earliness of internationalization and performance outcomes:

Exploring the moderating effects of venture age and international commitment. Journal of World Business, 49(1), 132-142. https://doi.org/10.1016/j.jwb.2013.10.001 


\section{List of figures}

Figure 1. Estimated trajectory of export propensity according to firm age (years)

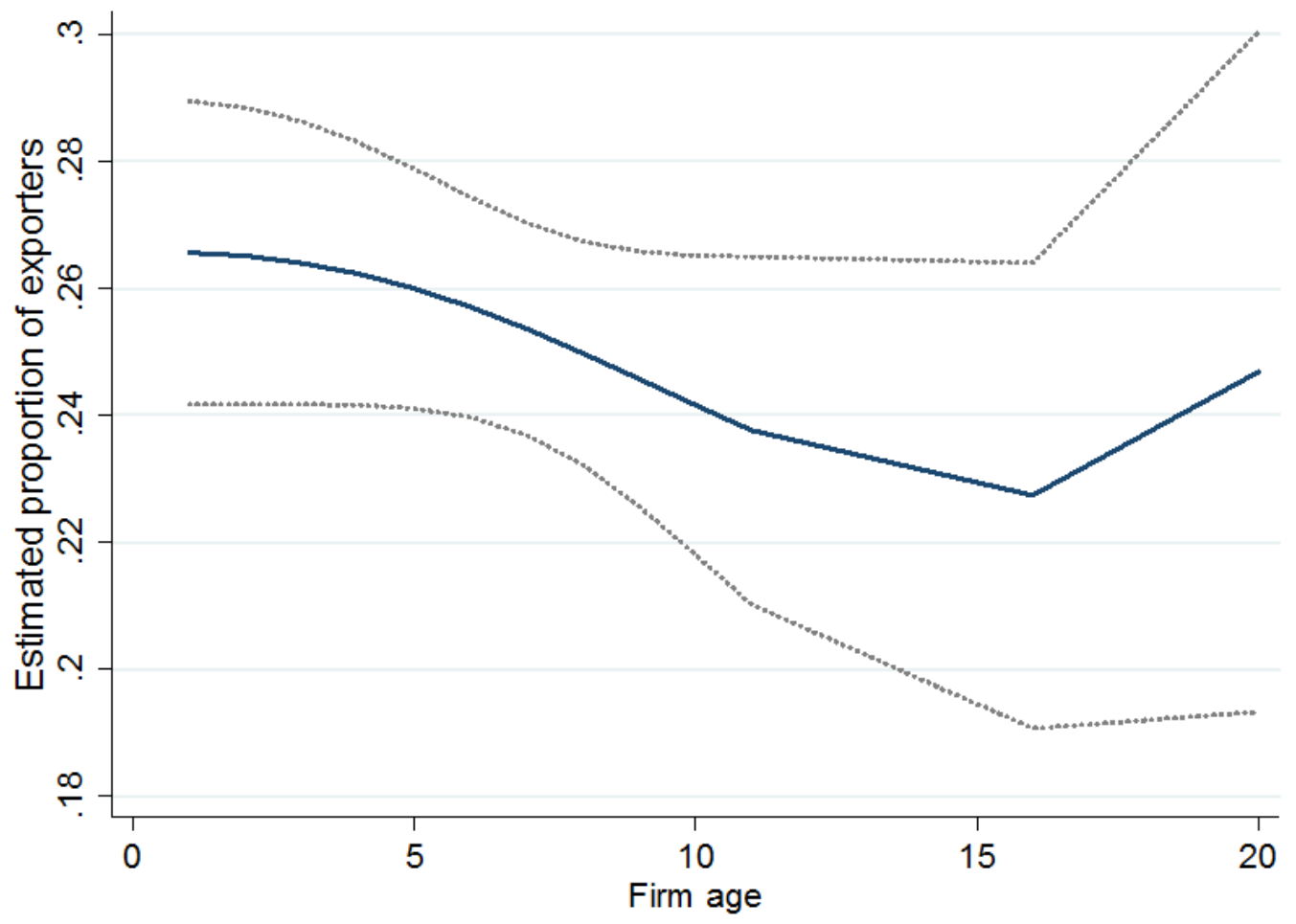

Note: The dotted line represents the $95 \%$ confidence interval. 
Figure 2. Estimated trajectory of low export intensity and firm age (years)

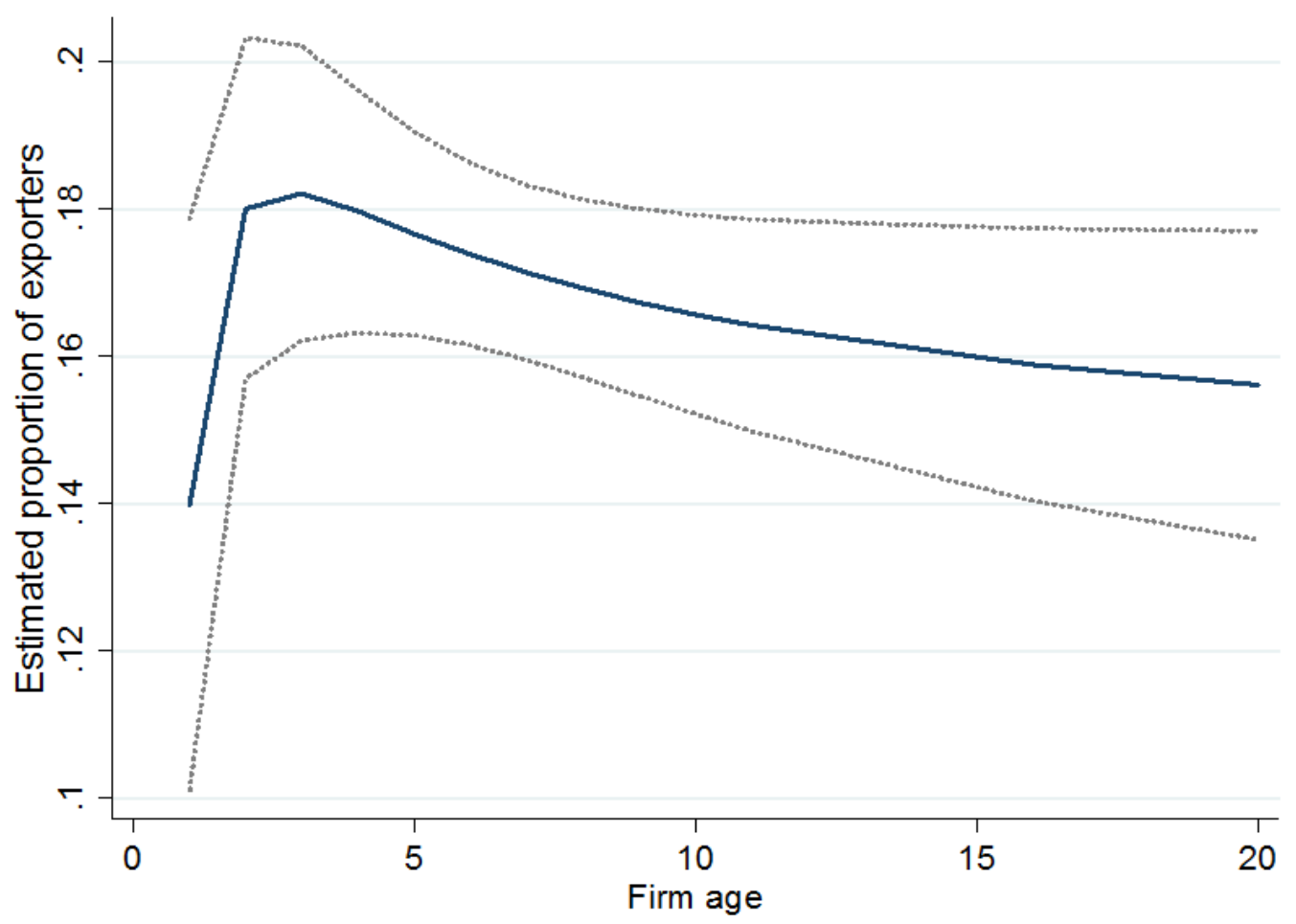

Note: The dotted line represents the $95 \%$ confidence interval.

Figure 3. Estimated trajectory of mid- and high-export intensity and firm age (years)

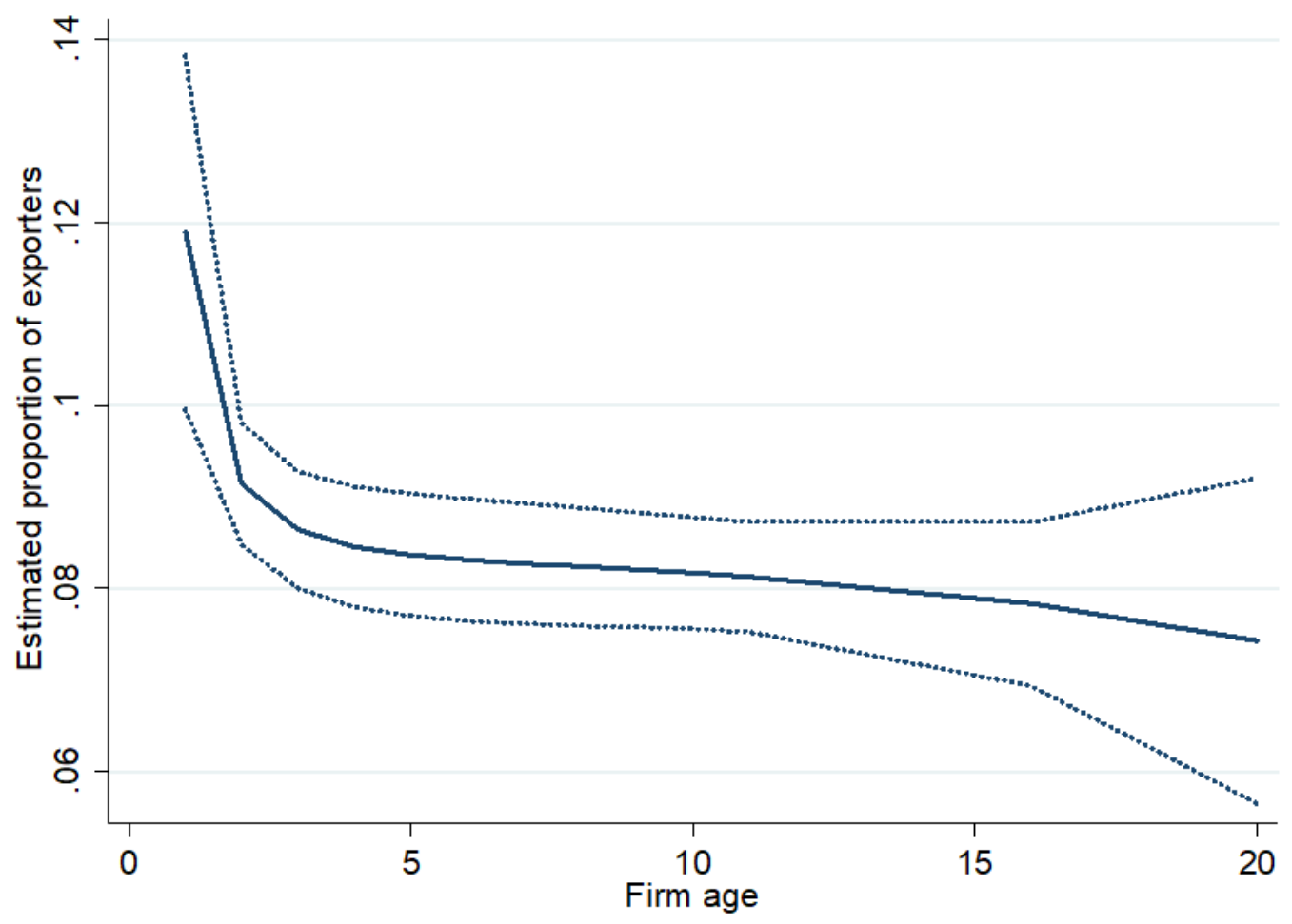

Note: The dotted line represents the 95\% confidence interval. 


\section{List of tables}

Table 1. Cohort size by time in the market and industry (period 2007-2012)

\begin{tabular}{|l|l|c|c|c|c|}
\hline N & Time / Sector & $\begin{array}{l}\text { Manufacturing } \\
\text { sectors }\end{array}$ & $\begin{array}{l}\text { Business } \\
\text { services }\end{array}$ & $\begin{array}{l}\text { Consumer } \\
\text { services }\end{array}$ & Total \\
\hline 1 & 1st year in the market & 614 & 552 & 1124 & 2290 \\
\hline 2 & 2nd year in the market & 219 & 155 & 373 & 747 \\
\hline 3 & 3rd year in the market & 238 & 181 & 370 & 789 \\
\hline 4 & 4th year in the market & 240 & 160 & 311 & 711 \\
\hline 5 & 5th year in the market & 184 & 156 & 326 & 711 \\
\hline 6 & 6th year in the market & 149 & 138 & 292 & 614 \\
\hline 7 & 7th year in the market & 172 & 98 & 247 & 510 \\
\hline 8 & 8th year in the market & 138 & 80 & 224 & 528 \\
\hline 9 & 9th year in the market & 172 & 125 & 273 & 572 \\
\hline 10 & 10th year in the market & 565 & 375 & 815 & 1755 \\
\hline 11 & 11th - 15th year in the market & 473 & 259 & 621 & 1353 \\
\hline 12 & 16th - 20th year in the market & 1044 & 384 & 1513 & 2941 \\
\hline 13 & More than 20 years in the market & $\mathbf{4 4 3 7}$ & $\mathbf{2 7 7 7}$ & $\mathbf{6 7 4 7}$ & $\mathbf{1 3 9 6 1}$ \\
\hline & Total & & & \\
\hline
\end{tabular}


Table 2. Descriptive statistics (observation level between 2007 and 2012)

\begin{tabular}{|c|c|c|c|c|c|c|}
\hline & \multicolumn{2}{|c|}{ New businesses } & \multicolumn{2}{|l|}{$\begin{array}{l}\text { Established } \\
\text { businesses }\end{array}$} & \multicolumn{2}{|c|}{ Full sample } \\
\hline & $\begin{array}{l}\text { Mean } \\
\text { (Std. dev) }\end{array}$ & Obs. & $\begin{array}{l}\text { Mean } \\
\text { (Std. dev) }\end{array}$ & Obs. & $\begin{array}{l}\text { Mean } \\
\text { (Std. dev) }\end{array}$ & Obs. \\
\hline Export propensity & $\begin{array}{c}0.3412 * * * \\
(0.4742)\end{array}$ & 2290 & $\begin{array}{c}0.2622 \\
(0.4398) \\
\end{array}$ & 11671 & $\begin{array}{c}0.2765 \\
(0.4473) \\
\end{array}$ & 13961 \\
\hline $\begin{array}{l}\text { Export intensity: } \\
\text { up to } 25 \%\end{array}$ & $\begin{array}{c}0.1732 \\
(0.3785) \\
\end{array}$ & 2290 & $\begin{array}{c}0.1783 \\
(0.3828) \\
\end{array}$ & 11671 & $\begin{array}{c}0.1774 \\
(0.3820) \\
\end{array}$ & 13961 \\
\hline $\begin{array}{l}\text { Export intensity: } \\
\text { between } 25 \% \text { and } 75 \%\end{array}$ & $\begin{array}{l}0.1028 * * * \\
(0.3038)\end{array}$ & 2290 & $\begin{array}{c}0.0538 \\
(0.2256)\end{array}$ & 11671 & $\begin{array}{c}0.0627 \\
(0.2424)\end{array}$ & 13961 \\
\hline $\begin{array}{l}\text { Export intensity: } \\
\text { more than } 75 \%\end{array}$ & $\begin{array}{c}0.0651 * * * \\
(0.2468)\end{array}$ & 2290 & $\begin{array}{c}0.0301 \\
(0.1708)\end{array}$ & 11671 & $\begin{array}{c}0.0364 \\
(0.1873)\end{array}$ & 13961 \\
\hline $\begin{array}{l}\text { Business size } \\
\text { (employees) }\end{array}$ & $\begin{array}{c}3.25 * * \\
(8.13)\end{array}$ & 2290 & $\begin{array}{c}4.26 \\
(19.06)\end{array}$ & 11671 & $\begin{array}{c}4.09 \\
(17.74)\end{array}$ & 13961 \\
\hline Manufacturing & $\begin{array}{l}0.2774 * * * \\
(0.4478)\end{array}$ & 2290 & $\begin{array}{c}0.3376 \\
(0.4729)\end{array}$ & 11671 & $\begin{array}{c}0.3266 \\
(0.4690)\end{array}$ & 13961 \\
\hline Business services & $\begin{array}{c}0.2444 * * * \\
(0.4298) \\
\end{array}$ & 2290 & $\begin{array}{c}0.1924 \\
(0.3942) \\
\end{array}$ & 11671 & $\begin{array}{c}0.2019 \\
(0.4014) \\
\end{array}$ & 13961 \\
\hline Consumer services & $\begin{array}{c}0.4782 \\
(0.4996)\end{array}$ & 2290 & $\begin{array}{c}0.4700 \\
(0.4991)\end{array}$ & 11671 & $\begin{array}{c}0.4715 \\
(0.4992)\end{array}$ & 13961 \\
\hline Gender (male) & $\begin{array}{c}0.5997 * * * \\
(0.4900) \\
\end{array}$ & 2290 & $\begin{array}{c}0.6304 \\
(0.4827) \\
\end{array}$ & 11671 & $\begin{array}{c}0.6248 \\
(0.4842) \\
\end{array}$ & 13961 \\
\hline Entrepreneur’s age & $\begin{array}{c}38.86 * * * \\
(10.72)\end{array}$ & 2290 & $\begin{array}{c}44.89 \\
(10.26)\end{array}$ & 11671 & $\begin{array}{c}43.79 \\
(10.61)\end{array}$ & 13961 \\
\hline Primary studies & $\begin{array}{c}0.2111^{* * *} \\
(0.4082) \\
\end{array}$ & 2290 & $\begin{array}{c}0.1763 \\
(0.3811) \\
\end{array}$ & 11671 & $\begin{array}{c}0.1827 \\
(0.3864) \\
\end{array}$ & 13961 \\
\hline Secondary studies & $\begin{array}{c}0.2483 * * * \\
(0.4321)\end{array}$ & 2290 & $\begin{array}{c}0.3274 \\
(0.4693) \\
\end{array}$ & 11671 & $\begin{array}{c}0.3129 \\
(0.4637) \\
\end{array}$ & 13961 \\
\hline Post-secondary studies & $\begin{array}{c}0.5396 * * * \\
(0.4985)\end{array}$ & 2290 & $\begin{array}{c}0.4944 \\
(0.5000)\end{array}$ & 11671 & $\begin{array}{c}0.5026 \\
(0.5000)\end{array}$ & 13961 \\
\hline
\end{tabular}

Standard deviation is presented in brackets. *,**, *** indicates significance at the $10 \%, 5 \%$ and $1 \%$, respectively. 
Table 3. Random effects regression results: The internationalization patterns (export propensity and intensity) of entrepreneurial firms

\begin{tabular}{|c|c|c|c|c|}
\hline & $\begin{array}{l}\text { Full model } \\
\text { (export propensity) }\end{array}$ & $\begin{array}{l}\text { Low export intensity } \\
\text { ( }<25 \% \text { of sales) }\end{array}$ & $\begin{array}{l}\text { Mid-level export intensity } \\
(25 \%<\text { exports }<75 \%)\end{array}$ & $\begin{array}{l}\text { High export intensity } \\
\text { (> 75\% of sales) }\end{array}$ \\
\hline 3rd year in the market & $-0.0169(0.0085)^{* *}$ & $0.0398(0.0153)^{* * *}$ & $-0.0239(0.0101)^{* *}$ & $-0.0249(0.0082)^{* * *}$ \\
\hline 4th year in the market & $-0.0155(0.0883)^{*}$ & $0.0386(0.0189)^{* *}$ & $-0.0250(0.0125)^{* *}$ & $-0.0320(0.0102)^{* * *}$ \\
\hline 5th year in the market & $-0.0129(0.0106)$ & $0.0608(0.0186)^{* * *}$ & $-0.0285(0.0122)^{* *}$ & $-0.0267(0.0100)^{* * *}$ \\
\hline 6th year in the market & $-0.0104(0.0111)$ & $0.0309(0.0185)^{*}$ & $-0.0145(0.0128)$ & $-0.0246(0.0104)^{* *}$ \\
\hline 7th year in the market & $-0.0008(0.0118)$ & $0.0224(0.0206)$ & $-0.0121(0.0136)$ & $-0.0160(0.0111)$ \\
\hline 8th year in the market & $-0.0117(0.0122)$ & $0.0138(0.0213)$ & $-0.0205(0.0140)$ & $-0.0194(0.0114)^{*}$ \\
\hline 9th year in the market & $-0.0191(0.0126)$ & $0.0311(0.0220)$ & $0.0053(0.0145)$ & $-0.0307(0.0118)^{* * *}$ \\
\hline 10th year in the market & $0.0046(0.0107)$ & $-0.0260(0.0186)$ & $0.0011(0.0123)$ & $0.0056(0.0100)$ \\
\hline More than 10 years in the market & $-0.0206(0.0123)^{*}$ & $0.0234(0.0213)$ & $-0.0092(0.0141)$ & $-0.0396(0.0115)$ \\
\hline Business size (ln employees) & $-0.0029(0.0053)$ & $0.0145(0.0090)$ & $-0.0054(0.0061)$ & $0.0052(0.0050)$ \\
\hline Business flow variation rate & $0.0485(0.0248)^{* *}$ & $0.0459(0.0196)^{* *}$ & $0.0006(0.0132)$ & $0.0131(0.0108)$ \\
\hline Gender (1 for male) & $-0.0037(0.0228)$ & $-0.0453(0.0389)$ & $-0.0071(0.0263)$ & $0.0363(0.0214)^{*}$ \\
\hline Age (ln years) & $0.0034(0.0470)$ & $-0.0132(0.0807)$ & $-0.0609(0.054)$ & $0.0252(0.0441)$ \\
\hline Education: secondary studies & $0.0258(0.0363)$ & $-0.1062(0.0617)^{*}$ & $0.0661(0.0398)^{*}$ & $0.0154(0.0341)$ \\
\hline Education: post-secondary studies & $0.0258(0.0305)$ & $-0.0641(0.0518)$ & $0.0429(0.0351)$ & $0.0286(0.0577)^{* * *}$ \\
\hline Year dummies & Yes & Yes & Yes & Yes \\
\hline Regional dummies & Yes & Yes & Yes & Yes \\
\hline Sector dummies & Yes & Yes & Yes & Yes \\
\hline Intercept & $-0.1165(0.1767)$ & $0.2770(0.3015)$ & $0.2492(0.2019)$ & $-0.0533(0.1648)$ \\
\hline Wald test (chi2) & $382.82 * * *$ & $268.08^{* * *}$ & $155.63^{* * *}$ & $76.05^{* * *}$ \\
\hline R2 (overall) & 0.6148 & 0.5649 & 0.4304 & 0.2696 \\
\hline Hausman specification test & $19.06(p$-value $=0.3880)$ & $18.02(p$-value $=0.4542)$ & $19.61(p$-value $=0.3550)$ & $6.89(p$-value $=0.9910)$ \\
\hline Observations & 234 & 234 & 234 & 234 \\
\hline
\end{tabular}

All model specifications are weighted by the square root of the cohort size (Deaton, 1985). The omitted regional variable is Madrid, 2012 is the omitted year dummy, and 'consumer services' is the omitted sector variable. Robust standard errors are presented in brackets. *, **, *** indicates significance at the $10 \%, 5 \%$, and $1 \%$ level, respectively. 
Table 4. Random effects regression results: Exports intensity

\begin{tabular}{|c|c|c|}
\hline & $\begin{array}{l}\text { Low export intensity } \\
\text { ( }<25 \% \text { of sales })\end{array}$ & $\begin{array}{l}\text { Mid and high export intensity } \\
\text { (> } 25 \% \text { of sales) }\end{array}$ \\
\hline 3rd year in the market & $0.0398(0.0153)^{* * *}$ & $-0.0483(0.0131) * * *$ \\
\hline 4th year in the market & $0.0386(0.0189)^{* *}$ & $-0.0566(0.0162)^{* * *}$ \\
\hline 5th year in the market & $0.0608(0.0186)^{* * *}$ & $-0.0555(0.0159)^{* * *}$ \\
\hline 6th year in the market & $0.0309(0.0185)^{*}$ & $-0.0391(0.0166)^{* *}$ \\
\hline 7th year in the market & $0.0224(0.0206)$ & $-0.0263(0.0077)$ \\
\hline 8th year in the market & $0.0138(0.0213)$ & $-0.0404(0.0184)^{* *}$ \\
\hline 9th year in the market & $0.0311(0.0220)$ & $-0.0277(0.0188)$ \\
\hline 10th year in the market & $-0.0260(0.0186)$ & $0.0077(0.0159)$ \\
\hline $\begin{array}{l}\text { More than } 10 \text { years in the } \\
\text { market }\end{array}$ & $0.0234(0.0213)$ & $-0.0503(0.0086)^{* * *}$ \\
\hline Business size (ln employees) & $0.0145(0.0090)$ & $0.0032(0.0080)$ \\
\hline Business flow variation rate & $0.0459(0.0196)^{* *}$ & $-0.0405(0.0237)^{*}$ \\
\hline Gender (1 for male) & $-0.0453(0.0389)$ & $0.0520(0.0385)$ \\
\hline Age (ln years) & $-0.0132(0.0807)$ & $-0.0411(0.0712)$ \\
\hline Education: secondary studies & $-0.1062(0.0617)^{*}$ & $0.1005(0.0544)^{*}$ \\
\hline $\begin{array}{l}\text { Education: post-secondary } \\
\text { studies }\end{array}$ & $-0.0641(0.0518)$ & $0.0587(0.0461)$ \\
\hline Year dummies & Yes & Yes \\
\hline Regional dummies & Yes & Yes \\
\hline Sector dummies & Yes & Yes \\
\hline Intercept & $0.2770(0.3015)$ & $0.1716(0.2649)$ \\
\hline Wald test (chi2) & $268.08^{* * *}$ & $202.76^{* * *}$ \\
\hline R2 (overall) & 0.5649 & 0.4985 \\
\hline Hausman specification test & $6.03(p$-value $=0.9961)$ & $7.07(p$-value $=0.8959)$ \\
\hline Observations & 234 & 234 \\
\hline
\end{tabular}

All model specifications are weighted by the square root of the cohort size (Deaton, 1985). The omitted regional variable is Madrid, 2012 is the omitted year dummy variable, and 'consumer services' is the omitted sector variable. Standard errors are presented in brackets. $*, * *, * * *$ indicates significance at the $10 \%, 5 \%$, and $1 \%$ level, respectively. 


\section{Appendix}

Table A1. Random effects regression results: Exports propensity

\begin{tabular}{|l|c|c|}
\hline & Model 1 & Model 2 \\
\hline 3rd year in the market & $-0.0169(0.0085)^{* *}$ & $0.0221(0.0228)$ \\
\hline 4th year in the market & $-0.0155(0.0883)^{*}$ & $0.0148(0.0247)$ \\
\hline 5th year in the market & $-0.0129(0.0106)$ & $0.0061(0.0240)$ \\
\hline 6th year in the market & $-0.0104(0.0111)$ & $-0.0027(0.0258)$ \\
\hline 7th year in the market & $-0.0008(0.0118)$ & $-0.0037(0.0278)$ \\
\hline 8th year in the market & $-0.0117(0.0122)$ & $-0.0157(0.0189)$ \\
\hline 9th year in the market & $-0.0191(0.0126)$ & $-0.0223(0.0306)$ \\
\hline 10th year in the market & $0.0046(0.0107)$ & $-0.0100(0.0263)$ \\
\hline More than 10 years in the market & $-0.0206(0.0123)^{*}$ & $-0.0377(0.0227)^{*}$ \\
\hline Manufacturing sector & & $-0.0941(0.0224)^{* * *}$ \\
\hline Manufacturing X 3rd year in the market & & $-0.0706(0.0417)^{*}$ \\
\hline Manufacturing X 4th year in the market & & $-0.0801(0.0401)^{* *}$ \\
\hline Manufacturing X 5th year in the market & & $-0.0149(0.0427)$ \\
\hline Manufacturing X 6th year in the market & & $0.0176(0.0468)$ \\
\hline Manufacturing X 7th year in the market & & $-0.0033(0.0505)$ \\
\hline Manufacturing X 8th year in the market & & $0.0050(0.0482)$ \\
\hline Manufacturing X 9th year in the market & & $0.0599(0.0569)$ \\
\hline Manufacturing X 10th year in the market & & $-0.0017(0.0458)$ \\
\hline $\begin{array}{l}\text { Manufacturing X More than 10 years in the } \\
\text { market }\end{array}$ & & $0.0138(0.0235)$ \\
\hline Business size (ln employees) & $-0.0029(0.0053)$ & $0.0184(0.0109)^{*}$ \\
\hline Business flow variation rate & $0.0485(0.0248)^{* *}$ & $-0.0552(0.0306)^{*}$ \\
\hline Gender (1 for male) & $-0.0037(0.0228)$ & $0.0747(0.0501)$ \\
\hline Age (ln years) & $0.0034(0.0470)$ & $-0.0397(0.0878)$ \\
\hline Education: secondary studies & $0.0258(0.0363)$ & $0.0164(0.0804)$ \\
\hline Education: post-secondary studies & $0.0258(0.0305)$ & $0.0281(0.0675)$ \\
\hline Year dummies & Yes & Yes \\
\hline Regional dummies & $-0.1165(0.1767)$ & $0.3172(0.3447)$ \\
\hline Intercept & $382.82^{* * *}$ & $581.82 * * *$ \\
\hline Wald test (chi2) & 0.6148 & 0.7480 \\
\hline R2 (overall) & 19.06 & 12.18 \\
\hline Hausman specification test & & 234 \\
\hline Observations & & Yes \\
\hline All value= 0.3880) & & $0.8379)$ \\
\hline
\end{tabular}

All model specifications are weighted by the square root of the cohort size (Deaton, 1985). The omitted regional variable is Madrid, 2012 is the omitted year dummy variable, and 'consumer services' is the omitted sector variable. Standard errors are presented in brackets. *, **, *** indicates significance at the $10 \%, 5 \%$, and $1 \%$ level, respectively. 